\title{
PENGARUH HARGA DAN KUALITAS PRODUKSI TERHADAP PENINGKATAN VOLUME PENJUALAN PADA PABRIK ROTI DUA CAKRA
}

\author{
Neti, Lin Magdalena \\ Fakultas Ilmu Sosial dan Ilmu Politik Universitas Kapuas \\ Email: $\underline{\text { linmagdalena@gmail.com }}$
}

\begin{abstract}
Abstrak : Tujuan yang ingin dicapai dari penelitian ini adalah untuk menemukan dan mengetahui serta menganalisis : (1) untuk mengetahui pengaruh harga secara parsial terhadap peningkatan volume penjualan pada Pabrik Roti Dua Cakra di Kabupaten Sanggau (2) untuk mengetahui pengaruh kualitas produk secara parsial terhadap peningkatan volume penjualan pada Pabrik Roti Dua Cakra di Kabupaten Sanggau; (3) Untuk mengetahui pengaruh harga dan kualitas produk secara simultan terhadap peningkatan volume penjualan pada Pabrik Roti Dua Cakra di Kabupaten Sanggau. Penelitian ini menggunakan jenis penelitian kuantitatif dengan populasi terdiri dari konsumen yang membeli roti di Pabrik Roti Dua Cakra di Kabupaten Sanggau. Dengan jumlah populasi yang tidak diketahui. Pengambilan sampel ditetapkan dengan menggunakan rumus Z score, jumlah sampel digenapkan menjadi 100 orang responden. Terdiri dari variabel bebas (harga dan kualitas produk) dan variabel terikat (volume penjualan. Analisis data menggunakan bantuan program SPPS 18 untuk melakukan Uji Regresi Linier Berganda, Uji t (Parsial), Uji F (Simultan) dan Uji Koefisien Determinasi.
\end{abstract}

Kata Kunci : Harga, Kualitas Produk, Volume Penjualan.

Menurut Daryanto (2013:62) "harga adalah jumlah uang yang ditagihkan untuk suatu produk atau sejumlah nilai yang dipertukarkan konsumen untuk manfaat memiliki atau menggunakan produk". Harga memegang peranan penting dalam memasarkan suatu produk. Bila harga terlalu mahal, maka produk tersebut akan tidak terjangkau oleh pasar maka volume penjualan akan menurun. Sebaliknya, jika harga terlalu murah, perusahaan sulit mendapatkan laba atau sebaliknya konsumen mempersepsikan kualitasnya tidak baik.

Menurut Tjiptono (2015:291) secara garis besar peranan harga dapat dijabarkan sebagai berikut: 1) Harga yang dipilih berpengaruh langsung terhadap tingkat permintaan dan menentukan tingkat aktivitas. Harga yang terlampau mahal atau sebaliknya harga yang terlalu murah berpotensi menghambat pengembangan produk. 2) Harga jual secara langsung menentukan profitabilitas operasi. 3) Harga yang ditetapkan oleh perusahaan mempengaruhi persipsi umum terhadap produk atau merk dan berkontribusi pada posisi merk. 4) Harga merupakan alat atau wahana langsung untuk melakukan perbandingan antar produk atau merk yang saling bersaing. 5) Strategi penetapan harga harus selaras dengan komponen bauran pemasaran lainnya. Harga harus dapat menutup biaya pengembangan, promosi dan distribusi produk.

Bila dikelola dengan baik keterjangkauan harga dapat menguntungkan kedua belah pihak yaitu perusahaan dan konsumen. Keuntungan bagi perusahaan dapat menjadikan konsumen sebagai pelanggan yang loyal terhadap perusahaan, dengan begitu konsumen akan selalu membeli produk yang mereka butuhkan kepada perusahaan bukan dengan perusahaan lain, dengan begitu perusahaan dapat keuntungan karena produk yang di produksi laris dipasaran karena telah memilki pelanggan tetap. Keuntungan bagi konsumen mendapatkan suatu produk dengan harga yang terjangkau sehingga dapat menghemat pengeluaran. Konsumen sering membandingkan harga suatu produk dengan produk lain yang sejenis, dalam hal ini mahal murahnya suatu produk sangat dipertimbangkan okeh konsumen pada saat akan membeli produk, peran perusahaan menyediakan harga produk yang sesuai kualitas produk dengan kemampuan konsumen.

Harga merupakan unsur bauran pemasaran yang bersifat fleksibel, artinya dapat diubah dengan cepat. Harga merupakan satuan moneter atau ukuran lainnya (termasuk barang dan jasa lainnya) yang ditukarkan agar memperoleh hak kepemilikan atau penggunaan suatu barang atau jasa. Harga merupakan komponen yang berpengaruh langsung terhadap laba perusahaan. Tingkat harga yang ditetapkan mempengaruhi kuantitas yang terjual. Selain itu, secara tidak langsung harga juga mempengaruhi biaya, karena kuantitas yang terjual berpengaruh pada biaya yang ditimbulkan dalam kaitannya dengan efisiensi produksi. Oleh karena itu, penetapan harga mempengaruhi pendapatan total dan biaya total, maka keputusan dan strategi penetapan harga memegang peranan penting dalam setiap perusahaan. Perusahaan dalam usaha memasarkan barang atau jasa, perlu penetapan harga yang tepat. 
Metode penetapan harga secara garis besar dapat dikelompokan menjadi empat kategori utama, yaitu metode pentapan harga berbasis permintaan, berbasis biaya,berbasis laba, dan berbasis persaingan. Metode penetapan harga tersebut di diterangkan oleh Tjiptono (2016: 226) metode-metode penetapan harga tersebut adalah sebagai berikut: 1) Metode Penetapan Harga Berbasis Permintaan; Adalah suatu metode yang menekankan pada faktor-faktor yang mempengaruhi selera dan referensi pelanggan dari faktor-faktor seperti biaya, laba, dan persaingan. 2) Metode Penetapan Harga Berbasis Biaya; Dalam metode penetapan harga, faktor penentu harga dalam metode ini yang utama adalah aspek penawaran atau biaya, bukan aspek permintaan. Harga ditentukan berdasarkan biaya produksi dan pemasaran yang ditambah dengan jumlah tertentu sehingga dapat menutupi biaya-biayalangsung, biaya overhead dan laba. 3) Metode Penetapan Harga Berbasis Laba; Metode ini berusaha menyeimbangkan pendapatan dan biaya dalam penetapan harganya. Upaya ini dapat dilakukan atas dasar target volume laba spesifik atau dinyatakan dalam bentuk persetase terhadap penjualan atau investasi. 4) Metode Penetapan Harga Berbasis Persaingan; Selain berdasarkan pada pertimbangan biaya, permintaan atau laba, harga juga dapat ditetapkan atas dasar persaingan, yaitu apa yang dilakukan pesaing.

Penetapan harga merupakan suatu masalah ketika perusahaan harus menentukan harga untuk pertama kali. Hal ini terjadi ketika perusahaan mengembangkan atau memperoleh suatu produk baru, ketika ia memperkenalkan produk lamanya ke saluran distribusi baru atau ke daerah geografis baru, dan ketika melakukan tender memasuki suatu tawaran kontrak kerja yang baru. Jika perusahaan tersebut telah memilih pasar sasaran dan penentuan posisi pasarnya dengan cermat, maka strategi bauran pemasarannya, termasuk harga, akan cukup mudah. Jadi strategi penetapan harga sangat ditentukan oleh keputusan yang menyangkut penempatan posisi pasar. Menentukan permintaan Setiap harga yang ditentukan perusahaan akan membawa kepada tingkat permintaan yang berbeda dan oleh karena itu penetapan harga selalu menjadi masalah bagi setiap perusahaan.

Menurut kotler dan Amstrong (2012:314) menjelaskan ada empat ukuran yang mencirikan harga yaitu keterjangkauan harga, kesesuaian harga dengan dengan kualitas, kesesuaian harga dengan manfaat, dan harga yang sesuai daya beli.
Berikut adalah penjelasan mengenai indikator harga : 1) Keterjangkauan Harga; Konsumen bisa menjangkau harga yang telah ditetapkan oleh perusahaan. Produk biasanya ada beberapa jenis dalam satu merek dan harganya juga berbeda dari yang termurah hingga yang termahal. Dengan harga yang ditetapkan para konsumen banyak yang membeli produk sesuai dengan kemampuan yang bisa dijangkau oleh para konsumen. 2) $\mathrm{H}$ a rg a Sesuai Kemampuan atau Daya Saing Harga; Konsumen sering membandingkan harga satu produk dengan produk lainnya. Dalam hal ini mahal murahnya harga suatu produk sangat dipertimbangkan oleh konsumen pada saat akan membeli produk tersebut. 3) Kesesuaian Harga dengan Kualitas Produk; Harga sering dijadikan indikator kualitas bagi para konsumen yang sering memilih harga yang lebih tingi diantaradua barang karena mereka melihat adanya perbedaan kualitas. Apabila harga produk lebih tinggi orang cenderung beranggapan bahwa kualitasnya juga lebih baik. 4) Kesesuaian Harga dengan manfaat; Konsumen memutuskan membeli suatu produk jika manfaat yang dirasakan lebih besar atau sama dengan yang telah dikeluarkan untuk mendapatkannya. Jika konsumen merasakan manfaat produk lebih kecil dari uang yang dikeluarkan maka konsumen beranggapan bahwa produk tersebut mahal dan konsumen akan berfikir dua kali untuk melakukan pembelian ulang.

Harga akan menjadi pertimbangan yang cukup tinggi bagi konsumen dalam memutuskan pembelian. Konsumen akan membandingkan harga dari produk pilihan mereka dan kemudian mengevaluasi kesesuaian harga tersebut dengan nilai produk atau jasa serta jumlah uang yang harus dikeluarkan.

Menurut Daryanto (2013:136) kualitas produk dapat diartikan sebagai kemampuan suatu produk baik barang maupun jasa dalam memenuhi kebutuhan konsumen. Selain itu produk dapat pula didefinisikan sebagai persepsi konsumen yang dijabarkan oleh produsen melalui hasil produksinya. Produk dipandang penting oleh konsumen dan dijadikan dasar pengambilan keputusan. Sedangkan menurut Kotler dan Keller (2009:143) kualitas produk adalah kemampuan suatu barang untuk memberikan hasil atau kinerja yang sesuai bahkan melebihi dari apa yang diiinginkan pelanggan. Kualitas produk merupakan pemahaman bahwa produk merupakan peluang ditawarkan oleh penjual mempunyai nilai jual lebih yang tidak dimiliki oleh produk dan membandingkan dengan produk yang ditawarkan oleh perusahaan pesaing. Maka dari itu pentingnya memberikan kualitas produk yang terbaik. 
Dapat disimpulkan bahwa kualitas produk merupakan suatu proses penilaian fungsifungsi penting yang dimiliki oleh suatu produk mengenai beberapa aspek seperti ketepatan, daya tahan produk, keandalan, kemudahan pengoperasian dan atribut penting lainnya sesuai dengan yang diinginkan dan dibutuhkan oleh konsumen. Konsumen senantiasa melakukan penilaian terhadap kinerja suatu produk, hal ini dapat dilihat dari kemampuan produk menciptakan kualitas produk dengan segala spesifikasinya sehingga dapat menarik minat konsumen untuk melakukan pembelian kembali terhadap produk tersebut. Berdasarkan bahasan di atas dapat dikatakan bahwa kualitas yang diberikan suatu produk dapat mempengaruhi minat beli ulang konsumen terhadap produk yang diberikan.

Pada hakikatnya, seseorang membeli suatu produk bukan hanya sekedar ingin memiliki produk tersebut. Para pembeli membeli barang atau jasa, karena barang atau jasa tersebut dapat digunakan sebagai alat untuk memuaskankebutuhan dan keinginannya. Dengan kata lain, seseorang membeli produk bukankarena fisik produk itu semata-mata, tetapi karena manfaat yang ditimbulkan dari produk yang dibelinya tersebut. Menurut Faktor-faktor yang mempengaruhi Kualitas Produk menurut Basu Swastha dan Irawan (2005:242) pada dasarnya produk yang dibeli konsumen dapat dibedakan atas lima tingkatan, yaitu : 1) Produk inti (core product), yang merupakan inti atau dasar yangsesungguhnya dari produk yang ingin diperoleh atau didapatkan oleh seorangpembeli atau konsumen dari produk tersebut. 2) Produk generik, adalah produk dasar yang mampu memenuhi fungsi produk yang paling dasar (perencanaan produk minimum agar dapat berfungsi). 3) Produk harapan adalah produk formal yang ditawarkan dengan berbagai atribut dan kondisinya secara normal (layak) diharapkan dan disepakati untuk dibeli.4) Produk pelengkap,yakni berbagai atribut produk yang dilengkapi atau ditambahi berbagai manfaat layanan, sehingga dapat memberikan tambahan kepuasan dan bisa dibedakan dengan produk pesaing. 5) Produk potensial, adalah segala macam tambahan dari perubahan yang mungkin dikembangkan untuk suatu produk di masa mendatang.

Faktor yang dapat mempenguruhi kualitas produk seperti yang dikemukakan diatas harus selalu diperhatikan oleh para pelaku bisnis yang menciptakan produk, karena konsumen selalu menilai kualitas produk itu sendiri, kemudian membandingkan produk tersebut dengan produk sejenis hasil perusahaan lain. Menurut Kotler dan Amtrong (2012:126) "kualitas produk (product quality) merupakan senjata strategi potensial untuk mengalahkan pesaing”. Kemampuan dari kualitas produk untuk menjatuhkan berbagai fungsi termasuk didalamnya ketahanan, ketepatan, handal, dan kemudahan dalam penggunaan.

Kualitas produk memiliki dimensi yang dapat digunakan untuk menganalisis karakteristik dari suatu produk. Menurut David Garvin dalam buku Tjiptono (2016:134) kualitas produk memiliki delapan dimensi sebagai berikut: 1) Kinerja,merupakan karakteristik operasi pokok dari produk inti yang dibeli. 2) Keistimewaan, yaitu sifat yang menunjang fungsi dasar pokok, 3) Keandalan, kesesuaian dengan persepsi pelanggan terhadap keandalan produk yang dinyatakan dengan kualitas produk yang produksi oleh perusahaan. 4) Kesesuaian, yaitu sejauh mana karakteristik desain dan operasi memenuhi standar yang telah ditetapkan sebelumnya. 5) Daya tahan, keterkaitan ketahanan berupa lama produk dapat digunakan atau mencerminkan suatu ukuran usaha operasi produk yang diharapkan dalam kondisi normal, 6) Ketepatan kualitas, produk yang dihasilkan dari perusahaan yang memberikan pengaruh positif dan tanggung jawab bahwa produk tersebut memiliki citra merek yang baik. 7) Gaya, menggambarkan tampilan dan rasa produk kepada pembeli. 8) Desain merupakan Totalitas fitur yang mempengaruhi tampilan, rasa dan fungsi produk berdasarkan kebutuhan pelanggan.

Keistimewaan dan gaya dari sebuah produk akan menjadi ciri khas dari produk itu sendiri, untuk melakukan hal istimewa tersebut diperlukan kinerja yang totalitas agar mendapatkan hasil yang sesuai dengan kualitas produk yang diinginkan oleh konsumen. Daya tahan dari sebuah produk tersebut harus diperhatikan agar konsumen yang menjadi pelanggan puas terhadap produk yang diciptakan. Dengan demikian perusahaan akan mendapatkan konsumen yang loyal.

Aktivitas penjualan banyak dipengaruhi oleh faktor yang dapat meningkatkan aktivitas perusahaan, oleh karena itu manajer penjualan perlu memperhatikan faktor-faktor yang mempengaruhi penjualan. Faktor-faktor yang mempengaruhi penjualan menurut Swastha (2005:86)) sebagai berikut : 1) Kondisi dan Kemampuan Penjual Kondisi dan kemampuan terdiri dari pemahaman atas beberapa masalah penting yang berkaitan dengan produk yang dijual, 2) Kondisi Pasar 
mempengaruhi kegiatan dalam transaksi penjualan baik sebagai kelompok pembeli atau penjual. Kondisi pasar dipengaruhi oleh beberapa faktor yakni : jenis pasar, kelompok pembeli, daya beli, frekuensi pembelian serta keinginan dan kebutuhannya. 3) Modal atau dana sangat diperlukan dalam rangka untuk mengangkut barang dagangan ditempatkan atau untuk membesar usahanya. Modal perusahaan dalam penjelasan ini adalah modal kerja perusahaan yang digunakan untuk mencapai target penjualan yang dianggarkan, misalnya dalam menyelenggarakan stok produk dan dalam melaksanaan kegiatan penjualan memerlukan usaha seperti alat transportasi, tempat untuk menjual, usaha promosi dan sebagainya. 4) Kondisi Organisasi Perusahaan Pada perusahan yang besar, biasanya masalah penjualan ini ditangani oleh bagian tersendiri, yaitu bagian penjualan yang dipegang oleh orang-orang yang ahli dibidang penjualan.

Untuk melihat volume penjualan dapat menggunakan indikator menurut Kotler (2014:147) indikator untuk mengukur volume penjualan adalah sebagai berikut: 1) Harga jual, merupakan hal-hal yang sangat penting dan mempengaruhi penjualan atas barang atau jasa yang dihasilkan. Apakah barang atau jasa yang ditawarkan oleh perusahaan dapat dijangkau oleh konsumen sasaran. 2) Produk,salah satu faktor yang mempngaruhi tingkat volume penjualan sebagai barang atau jasa yang ditawarkan oleh perusahaan apakah sesuai dengan tingkat kebutuhan para konsumen. 3) Promosi, Promosi adalah aktivitas-aktivitas sebuah perusahaan yang dirancang untuk memberikan informasi-informasi membujuk pihak lain tentang perusahaan yang bersangkutan dan barang-barang serta jasa-jasa yang ditawarkan. 4) Saluran distribusi. Saluran distribusi merupakan aktivitas perusahaan untuk menyampaikan dana menyalurkan barang yang ditawarkan oleh perusahaan kepada konsumen yang diujinya. 5) Mutu dan kualitas barang,Mutu dan kualitas barang merupakan salah satu faktor yang mempengaruhi volume penjualan. Dengan mutu yang baik maka konsumen akan tetap loyal terhadap produk dari perusahaan tersebut, begitu pula sebaliknya apabila mutu produk yang ditawarkan tidak bagus maka konsumen akan berpaling kepada produk lain.

Setiap perusahaan memiliki strategi tertentu untuk meningkatkan volume penjualan, akan sangat baik jika strategi yang digunakan unik berbeda dengan perusahaan lain bisa lebih ditingkatkan melalui indikator seperti yang telah diterangkan diatas dan bisa juga dengan cara mengingkatkan kualitas pelayanan untuk membedakannya dengan perusahaan lain.

Menurut Dharmesta dan Irawan dalam Kamelia (2006:98) mengemukakan hubungan antara harga dan volume penjualan dalam pernyataan sebagai berikut "untuk beberapa jenis barang, harga dan volume penjualan berbanding terbalik; artinya jika terjadi kenaikan harga maka penjualan akan menurun dan jika terjadi penurunan harga maka penjualan akan akan meningkat". Menurut Dharmesta dan Irawan dalam Kamelia (2006:115) mengemukakan hubungan antara harga dan kualitas terhadap volume penjualan melalui dua sifat permintaan sebagai berikut: 1) Inelastis jika permintaan itu bersifat inelastis, maka perubahan harga akan mengakibatkan perubahan yang lebih kecil pada volume penjualan. 2) Elastis apabila permintaan itu elastis maka perubahan harga akan menyebabkan terjadinya perubahan volume penjualan dan perbandingan yang besar.

Dari pernyataan-pernyataan yang dikemukakan oleh para ahli di atas dapat disimpulkan bahwa harga jual merupakan hal yang cukup berperan dalam pencapain target perusahaan yang berkaitan dengan volume penjualan.

Kemampuan perusahaan dalam menjual produknya menentukan keberhasilan dalam mencari keuntungan, apabila perusahaan tidak mampu menjual maka perusahaan akan mengalami kerugian. Menurut Basu Swastha DH (2005 : 404) meningkatkan kualitas produk terhadap volume penjualan dalam perusahaan yaitu : 1) Mencapai volume penjualan yang tinggi, 2) Mendapatkan laba tertentu, 3) Menunjang pertumbuhan perusahaan, 4) Mendapatkan konsumen yang loyal

\section{KERANGKA BERPIKIR}

Volume penjualan merupakan semua jumlah total yang dihasilkan oleh kegiatan penjualan barang. Semakin tinggi jumlah barang yang diperjual belikan, maka kemungkinan besar pula laba yang akan diperoleh perusahaan.Untuk meningkatkan volume penjualan maka perusahaan harus memperhatikan kualitas produk yang terbaik agar konsumen jatuh hati pada produk tersebut. Agar produk yang dihasilkan dapat dinikmati semua kalangan masyarakat maka perusahaan harus cerdas dalam menentukan harga agar dapat dinikmati seluruh lapisan masyarakat. Berdasarkan dari uraian diatas, maka kerangka berfikir penelitian ini dapat digambarkan sebagai berikut : 
Gambar 1. Kerangka Berpikir

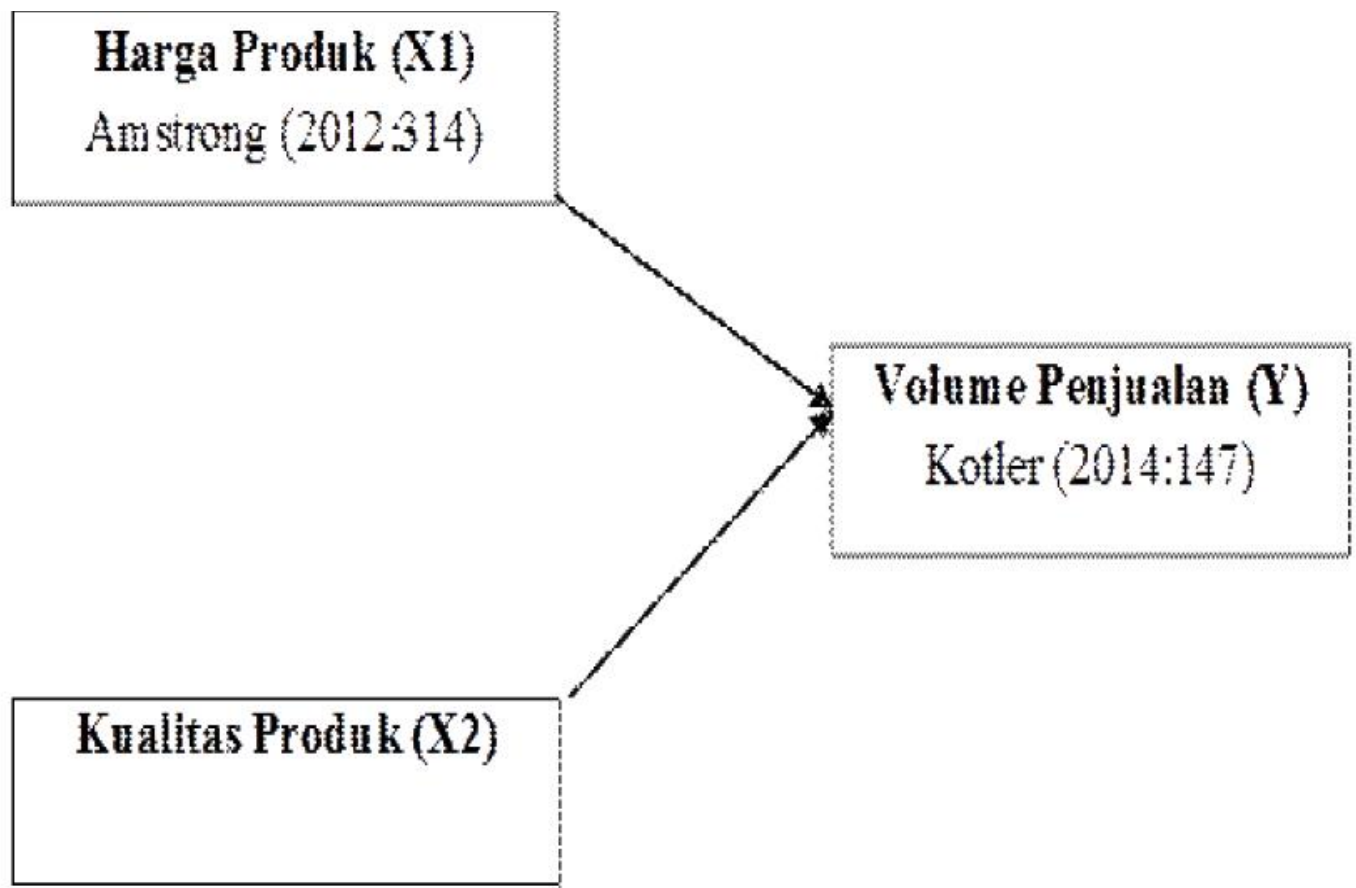

\section{HIPOTESIS}

Menurut Sugiono (2017:105) Hipotesis dapat diartikan sebagai satu jawaban yang bersifat sementara terhadap permasalahan penelitian, sampai terbukti melalui data. Berdasarkan pada permasalahan yang diteliti, maka peneliti menarik suatu hipotesis sebagai berikut:

1. Ho : Harga produk tidak berpengaruh positif dan signifikan terhadap peningkatan volume penjualan pada pabrik Roti Dua Cakra Kabupaten Sanggau.

Ha : Harga produk berpengaruh positif dan signifikan terhadap peningkatan volume penjualan pada pabrik Roti Dua Cakra di Kabupaten Sanggau.

2. Ho : Kualitas produk tidak berpengaruh positif dan signifikan terhadap peningkatan volume penjualan pada pabrik Roti Dua Cakra di Kabupaten Sanggau

$\mathrm{Ha}$ :Kualitas produk berpengaruh positif dan signifikan terhadap peningkatan volume penjualan pada Pabrik Roti Dua Cakra Kabupaten Sanggau.

3. Ho : Harga dan kualitas produk berpengaruh positif dan signifikan terhadap peningkatan volume penjualan pada pabrik Roti Dua Cakra di Kabupaten Sanggau.

Ha : Harga dan kualitas produk berpengaruh positif dan signifikan terhadap peningkatan volume penjualan pada pabrik Roti Dua Cakra di Kabupaten Sanggau.

\section{OBJEK DAN METODE PENELITIAN}

Penelitian ini akan dilaksanakan di Pabrik Roti Dua Cakra yang bertepatan di Kabupaten Sanggau. Dengan objek yang akan diteliti adalah konsumen yang menjadi pelanggan. Mengenai Pengaruh harga dan kualitas produk terhadap peningkatan volume penjualan pada Pabrik Roti Dua Cakra di Kabupaten Sanggau. Menurut Sugiyono (2017:112) bila dilihat dari landasan filsafat, data dan analisisnya "metode penelitian dikelompokan menjadi tiga, yaitu metode penelitian kuantitatif, metode penelitian kualitatif metode penelitian kombinasi (mixed methods) . Penelitian diartikan sebagai upaya atau kegiatan menyusun, menemukan pengetahuan dan ilmu dengan menggunkan metode-metode tertentu dan prosedur sistematis". Sementara pendekatan secara kuantitatif dapat digunakan sebagai metode penelitian yang berlandaskan pada filsafat positivisme, digunakan untuk meneliti pada populasi atau sampel tertentu, pengumpumpulan data menggunakan instrumen penelitian,analisis data bersifat kuantitatif/statistik, dengan tujuan untuk menggambarkan dan menguji hipotesis yang telah di tetapkan. Ada pun yang menjadi populasi dalam penelitian ini adalah konsumen yang yang menjadi pelanggan di pabrik roti Dua Cakra yang tidak dapat ditentukan jumlahnya. Teknik pengambilan sampel dalam penelitian ini menggunakan teknik probability sampling yaitu simple random sampling. Besarnya sampel yang diambil untuk penelitian ini sebanyak 100 konsumen yang merupakan agen distributor dari Pabrik Roti Dua Cakra di Kabupaten Sanggau. Pengumpulan data menggunakan koesioner dan dokumentasi. Berdasarkan tujuan yang akan 
dicapai dalam penelitian ini, maka data dianalisis secara deskriptif dan kuantitatif. Analisis yang digunakan adalah sebagai berikut: 1. Uji Validitas; 2. Uji Reliabilitas; 3. Uji Hipotesis.

\section{HASIL PENELITIAN DAN PEMBAHASAN}

\section{Uji Validitas}

Uji validitas dilakukan oleh peneliti terhadap variabel penelitian. Seperti dikemukakan sebelumnya penelitian ini menggunakan tiga

Tabel 1. Hasil Uji Validitas variabel. Adapun variabel yang dimaksud didalam penelitian ini terdiri dri dua variabel bebas yaitu harga (X1) dan kualitas produk (X2), serta satu variabel terikat yaitu volume penjuaalan (Y). Semua variabel dilakukan terhadap 100 dengan menjawab semua pernyataan pada kuesinoner. Pengujian terhadap ke empat variabel tersebut untuk melihat kelayakan dari angket kuesioner, apakah layak atau tidak untuk dijadikan instrumen dalam melakukan analisis data. Analisis data dilakukan menggunakan program SPSS 18.

\begin{tabular}{|c|c|c|c|c|}
\hline \multicolumn{5}{|c|}{ Variabel Harga $(\mathrm{X} 1)$} \\
\hline No & Pernyataan & $\begin{array}{l}\text { Person } \\
\text { Correlation }\end{array}$ & Sig (2-tailed) & Ket \\
\hline X1.1 & Harga sesuai kemampuan konsumen & $.831^{* *}$ & .000 & Valid \\
\hline $\mathrm{X} 1.2$ & Bersaing dengan produk lain & $.731^{* 8}$ & .000 & Valid \\
\hline $\mathrm{X} 1.3$ & Memiliki kualitas yang baik & $.394^{* *}$ & 000 & Valid \\
\hline $\mathrm{X} 1.4$ & Harga sesuai mamfaat produk & $.451^{\neq}$ & .000 & Valid \\
\hline \multicolumn{5}{|c|}{ Variab el Kualitas Produk (X2) } \\
\hline $\mathrm{X} 2.1$ & Kinerja yang dihasilk an karyawan & $.514^{* *}$ & 000 & Valid \\
\hline $\mathrm{X} 2.2$ & Memilikinilai istinewa & $.452^{* 3}$ & .000 & Valid \\
\hline $\mathrm{X} 2.3$ & Keandalan dalam pelayanan & $.617^{*}$ & 000 & Valid \\
\hline $\mathrm{X} 2.4$ & Kualitas sesuai harga & $.392^{* *}$ & .000 & Valid \\
\hline $\mathrm{X} 2.5$ & Daya talian produle & $.602^{* *}$ & .000 & Valid \\
\hline $\mathrm{X} 2.6$ & Menggunahan bahan terbaik & $.411^{*}$ & .000 & Valid \\
\hline $\mathrm{X} 2.7$ & Desain produk menarik & $.434^{* *}$ & 000 & Valid \\
\hline \multicolumn{5}{|c|}{ Variab el Volume Penjualan (Y) } \\
\hline Y.1 & Harga yang terjangkan & $837^{* *}$ & .000 & Valid \\
\hline Y.2 & Memiliki kualitas produk yang baik & $779^{* *}$ & .000 & Yalid \\
\hline Y. .3 & Promosi langsung dan tidak langsung & $617^{* *}$ & .000 & Valid \\
\hline Y.4 & Hasil produksi tersebar has & $496^{* *}$ & .000 & Valid \\
\hline Y.5 & Mutu dan kualitas terbaik & $458^{2 *}$ & .000 & Valid \\
\hline
\end{tabular}

Sumber: Kuesioner, Diolah Tahun 2020

Data pada tabel hasil pengolahan data menunjukan seluruh pernyataan yang terdapat pada variabel Harga (X1), kualitas produk (X2) dan volume penjualan $(\mathrm{Y})$ dengan probabilitas hasil korelasi (Sig. (2-tailed) lebih kecil dari 0,05 atau $5 \%$. Dengan demikian seluruh pernyataan yang berhubungan dengan harga (X1) kualitas produk (X2) dan volume penjualan (Y) layak digunakan sebagai instrumen dalam penelitian ini.

\section{Uji Reliabilitas}

Untuk menguji reliabilitas dilakukan dengan menggunakan koefisien reliabilitas (Cronbach Alpha). Instrumen dapat dikatakan andal (reliabel) bila memiliki koefisien keandalan reliabilitas sebesar 0,6 atau lebih. Hasil uji reliabilitas instrumen kuesioner terdapat dalam lampiran. Dapat disimpulkan dalam Tabel 2 berikut ini: 
Neti, Lin Magdalena, Pengaruh Harga dan Kualitas Produksi Terhadap Peningkatan Volume Penjualan 83

Tabel 2. Uji Reliabilitas

\begin{tabular}{|l|c|c|c|}
\hline \multicolumn{1}{|c|}{ Variabel } & $\begin{array}{c}\text { Cronbach's } \\
\text { Alpha }\end{array}$ & $\begin{array}{c}\text { Cronbach alpha } \\
\text { standar }\end{array}$ & Keterangan \\
\hline Harga (X1) & 0.703 & 0.6 & Reliabel \\
Kualitas Produk (X2) & 0.790 & 0.6 & Reliabel \\
Volume Penjualan (Y) & 0.837 & 0.6 & Reliabel \\
\hline
\end{tabular}

Sumber:Kuesioner, Diolah Tahun 2020

Berdasarkan tabel diatas, menunjukkan bahwa nilai alpha instrumen penelitian pada masing-masih variabel lebih besar dari nilai yang di isyaratkan, yaitu sebesar 0.6 atau lebih besar dari 0.6. Variabel harga, (X1) memiliki nilai Cronbach's Alpha sebesar 0,703 lebih besar dari pada 0,6 . Variabel kualitas produk (X2) memiliki

nilai Cronbach's Alpha sebesar 0, 790 lebih besar dari pada 0,6. Variabel volume penjualan (Y) memiliki nilai Cronbach's Alpha sebesar 0,837 lebih besar dari pada 0,6. Dengan demikian, keseluruhan instrumen kuesioner dalam penelitian ini adalah reliabel (dapat dipercaya) karena telah memenuhi syarat minimal.

\section{Pengujian Hipotesis}

Tabel 3 Hasil Uji Analisis Regresi Linier Berganda

\begin{tabular}{|c|c|c|c|c|c|c|}
\hline \multirow{2}{*}{\multicolumn{2}{|c|}{ Model }} & \multicolumn{2}{|c|}{ Unstandardized Coefficients } & Standardized & \multirow[b]{2}{*}{$\mathrm{T}$} & \multirow[b]{2}{*}{ Sig. } \\
\hline & & B & Std. Error & Beta & & \\
\hline \multirow[t]{3}{*}{1} & (Constant) & .082 & .125 & & .410 & .611 \\
\hline & HARGA & .184 & .033 & .328 & 7.285 & .000 \\
\hline & PRODUK & .453 & .026 & .529 & 6.912 & .000 \\
\hline
\end{tabular}

Sumber: Data Primer, Diolah Tahun 2020

Berdasarkan persamaan regresi diatas a0 $=0,082$ memiliki makna nilai konstanta ini menunjukan bahwa apabila tidak ada variabel harga (X1) dan variabel kualitas produk (X2), maka akan berpengaaruh positif terhadap variabel volume penjualan roti pada Pabrik Roti Dua Cakra di Kabupaten Sanggau. Nilai al =0,184 merupakan nilai koefiisien regresi variabel factor variabel harga (X1), artinya seccara parsial variabel harga $(\mathrm{X} 1)$ berpengaruh positif terhadap variabel variabel volume penjualan (Y) pada Pabrik Roti Dua Cakra di Kabupaten Sanggau, dengan asumsi bahwa variabel kualitas produk

Tabel 4. Hasil Uji F

\begin{tabular}{|l|r|r|r|r|r}
\hline Model & Sum of Squares & Df & Mean Square & F & \multicolumn{1}{c}{ Sig. } \\
\cline { 2 - 6 } 1 Regression & 358.113 & & 179.056 & $\mathbf{2 5 4 0 . 3 1 7}$ & .000 \\
Residual & 430.797 & 97 & .041 & & \\
\multicolumn{1}{c|}{ Total } & 788.910 & 99 & & & \\
\hline
\end{tabular}

Sumber: Koesioner , Diolah Tahun 2020
(X2) dianggap tetap atau konstan. Nilai a2 $=0,453$ merupakan nilai koefisien regresi variabel kualitas produk (X2) berpengaruh positif terhadap variabel volume penjualan (Y) roti pada Pabrik Roti Dua Cakra di Kabupaten Sanggau dengan asumsi bahwa variabel harga (X1) di anggap tetap atau konstan. Dengan demikian dapat disimpulan bahwa hasil uji regresi berganda adalah harga (X1) dan kualitas produk (X2) berpengaruh terhdap volume penjualan (Y) pada Pabrik Roti Dua Cakra di Kabupaten Sanggau. 
Berdasarkan hasil perhitungan dengan bantuan program SPSS 18 diperoleh nilai signifikan $\mathrm{F}$ hitung $=179.056$ dan nilai signifikan $=0,00<0,05$ menunjukan bahwa, variabel bebas (harga dan kualitas produk ) berpengaruh signifikan terhadap variabel terikat (volume penjualan) dimana nilai signifikan $0.00<0,05$ artinya variabel bebas secara bersama-sama (simultan) berpengaruh signifikan terhadap variabel terikat.

Tabel 5. Hasil Uji T

\begin{tabular}{|c|c|c|c|c|c|c|}
\hline & & Unstandardizec & Coefficients & Standardized & & \\
\hline & & B & Std. Error & Beta & $\mathbf{t}$ & Sig. \\
\hline 1 & (Constant) & 0.82 & .125 & & .410 & .611 \\
\hline & HARGA & .184 & .033 & .328 & 7.285 & .000 \\
\hline & PRODUK & .453 & .026 & .529 & 6.912 & .000 \\
\hline
\end{tabular}

Sumber: Kuesioner, diolah Tahun 2020

Pengaruh harga (X1) terhadap volume penjualan (Y) roti pada Pabrik Roti Dua Cakra di Kabupaten Sanggau diperoleh nilai thitung 7.285 dan probabilitas Sig $(0,00)<(0,05)$. Keputusan uji hipotesis dengaan menerima Ha berarti terdapat pengaruh harga secara parsial variabel terhadap volume penjualan pada Pabrik Roti Dua Cakra di Kabupaten Sanggau dengan memberikan pengaruh positif terhadap volume penjualan pada Pabrik Roti Dua Cakra di Kabupaten Sanggau. Artinya semakin baik atau meningkat variabel harga (X1) berupa harga yang sesuai dengan kemampuan konsumen, bersaing dengan produk lain, memiliki kualitas yang baik serta harga sesuai dengan manfaat produk akan menyebabkan peningkatan terhadap volume penjualan roti pada Pabrik Roti Dua Cakra di Kabupaten Sanggau.

Tabel 6. Analisis Koefisien Determinan (KD)
Pengaruh kualitas produk (X2) terhadap volume penjualan (Y) di Pabrik Roti Dua Cakra Kabupaten Sanggau diperoleh dari nilai thitung $=6.912$ dan probalilitas Sig $(0,00)<(0,05)$. Keputusan uji hipotesis dengan menerima Ha yang artinya terdapat pengaruh kualitas produk secara parsial tehadap volume penjualan (Y) di Pabrik Roti Dua Cakra Kabupaten Sanggau. Artinya semakin baik atau meningkatnya variabel kualitas produk (X2) berupa kinerjanya yang diberikan karyawan menghasilkan produk berkualitas, memiliki nilai istimewa, dimata konsumen, keandalan dalam pelayanan, kualitas sesuai harga, daya tahan produk, menggunakan bahan terbaik dan memiliki desain yang unik menyebabkan peningkatan volume penjualan roti di Pabrik Roti Dua Cakra Kabupaten Sanggau.

\begin{tabular}{|c|c|c|c|c|}
\hline Model & $\mathrm{R}$ & R Square & $\begin{array}{c}\text { Adjusted } R \\
\text { Square }\end{array}$ & $\begin{array}{l}\text { Std. Error of the } \\
\text { Estimate }\end{array}$ \\
\hline 1 & $.874^{\mathrm{a}}$ & .854 & .843 & 2.107 \\
\hline
\end{tabular}

Sumber: Koesioner, Diolah Tahun 2020

Koefisien korelasi ganda r (Multiple R) sebesar 0,874 mendekati 1, yang berarti antara fattor variabel harga (X1), variabel kualitas produk (X2) dengan volume penjualan (Y) pada Pabrik Roti dua Cakra di Kabupaten Sanggau menunjukan hubungn atau korelasi yang kuat dan searah (positif). Koefisien determinasi ( $R$ Square atau $\mathrm{R}^{2}$ ) yaitu untuk mengetahui besarnya pengaruh variabel independent $(\mathrm{X})$ terhadap variabel dependen (Y). Dari tabel di atas diperoleh hasil nilai R Square sebesar 0,854 , artinya bahwa $(0,854 \times 100 \%)=85,4 \%$ variabel volume penjualan pada Pabrik Roti Dua Cakra di kabupaten Sanggau akan dipengaruhi oleh variabel harga (X1) dan variabel kualitas produk (X2) sedangkan sisanya sebesar $(100 \%$ - 85,4\%) $=14,6 \%$ dipengaruhi oleh factor lain diluar persamaan model regresi.

\section{KESIMPULAN DAN SARAN}


Terdapat hubungan antara harga dan kualitas produk terhadap peningkatan volume penjualan roti pada Pabrik Roti Dua Cakra di Kaabupaten Sanggau yang digambarkan melalui persamaan regresi linier berganda $\mathrm{Y}=0.082+$ $0.184 \mathrm{X} 1+0.453 \mathrm{X} 2$. Ini menunjukan adanya hubungan positif antara variabel harga dan kualitas produk terhadap peningkatan volume penjualan. Ini artinya peningkatan dari variabel harga dan kualitas produk akan menyebabkan peningkatan volume penjualan pada Pabrik Roti Dua Cakra di Kabupaten Sanggau. Terdapat pengaruh harga secara parsial terhadap volume penjualan pada Pabrik Roti Dua Cakra di Kabupaten Sanggau ini terlihat dari nilai thitung $=7.285$ dan $\operatorname{Sig}(0,00)<$ $(0,05)$, artinya semakin baik atau meningkat variabel harga akan menyebabkan peningkatan terhadap volume penjualan roti pada Pabrik Roti Dua Cakra di Kabupaten Sanggau. Terdapat pengaruh kualitas produk secara parsial terhadap peningkatan volume penjualan pada Pabrik Roti Dua Cakra di Kabupaten Sanggau. Ini terlihat dari nilai t hitung $=6.912$ dan Sig $(0,00)<(0,05)$. Artinya semakin baik atau meningkatnya variabel kualitas produk menyebabkan peningkatan volume penjualan di Pabrik Roti Dua Cakra Kabupaten Sanggau. Terdapat pengaruh harga dan kualitas produk secara simultan terhadap peningkatan volume penjualan pada Pabrik Roti Dua Cakra di Kabupaten Sanggau dengan snilai $\mathrm{F}$ hitung $=$ 179.056 dan nilai signifikan $=0,00<0,05$ menunjukan bahwa, variabel bebas (harga dan kualitas produk ) berpengaruh signifikan terhadap variabel terikat (volume penjualan) pada Pabrik Roti Dua Cakra di Kabupaten Sanggau. Koefisien determinasi (R Square atau R2) sebesar 0,854, artinya bahwa $(0,854 \times 100 \%)=85,4 \%$ variabel volume penjualan pada Pabrik Roti Dua Cakra di kabupaten Sanggau akan dipengaruhi oleh variabel harga (X1) dan variabel kualitas produk (X2) sedangkan sisanya sebesar $(100 \%-85,4 \%)=$ $14,6 \%$ dipengaruhi oleh factor lain diluar persamaan model regresi. Berdasarkan kesimpulan diatas, peneliti memberikan beberapa saran sebagai berikut: Sebaiknya variabel harga terus dikaji dan dilakukan evaluasi untuk lebih meningkatkan volume penjualan pada Pabrik Roti Dua Cakra di Kabupaten Sanggau. Diharapkan Pabrik Roti terus memberikan kualitas produk yang terbaik untuk para konsumenya, agar konsumen menjadi loyal berlangganan, sehingga dapat meningkatkan volume penjualan pada Pabrik Roti Dua Cakra di Kabupaten Sanggau. Sebaiknya pihak Pabrik Roti Dua Cakra di Kabupaten Sanggau meningkatkan promosi dan melakukan analisis pasar serta evaluasi terhadap harga jual dan kualitas produk agar mampu memasarkan hasil produksi lebih luas lagi dari sebelumnya agar dapat meningkatkan volume penjualan roti di Pabrik Roti Dua Cakra di Kabupaten Sanggau.

\section{DAFTAR PUSTAKA}

Arikunto. 2006. Prosedur Penelitian Suatu pendekatan Praktik. Jakarta : PT Bineka

Cipta.

Daryanto. 2013. Manajemen Pemasaran. Bandung :PT. Sarana Tutorial Nurani Sejahtera Djali.2008. Metode Penelitian Suatu Pendekatan Proposal. Jakarta : PT Bumi Aksara Ghozali. 2012. Metodologi Penelitian ilmiah. Bandung : Bumi Aksara

Handoko. 2011. Bauran Pemasaran dan Loyalitas Konsumen. Bandung: Alfabeta

Irawan. 2006. Metode Pendekatan Kuantitatif. Jakarta :liberty

Kamelia. 2006. Prinsip Pemasaran. Jilid 1 dan 2 Edisi Ke 7.Jakarta :Erlangga

Kotler, Amstrong. 2012. Manajemen Pemasaran. Yogyakarta :IKAPI Kotler. 2014. DasarDasar Pemasaran. Edisi 9, Jilid 1. PT Indeks:Bandung.

Kotler. Killer 2016. Manajeman Pemasaran. JiJilid 1 Edisi Ke-12, Jakarta: Erlangga

.2016, Manajemen produk dan jasa Edisi ke 13, Yogyakarta.

Penerbit:Erlangga

Pakpahan, efenfi. 2009. Strategi Pemasaran. Yogyakarta:CV Andi offiset Philip Kotler. 2016. Prinsip-Prinsip pemasaran. Edisi ke1-2. Jakarta: Erlangga Purba.2006. metode Penelitian. Jakarta : Gratalia Indonesia

Sugiono. 2017. Metode Penelitian Bisnis. Bandung : Alfabeta Bandung

Swasta, Bayu. 2015. Manajemen Pemasaran dan Analisis Perilaku Konsumen.

Yogyakarta : BPFE

Tjiptono. 2015. Manajemen Produk dan Jasa. Yogyakarta:Rajawali Pers

Wibioso. 2003. Metode Penelitian Kuantitatif. Jakarta : BPFE-UI 